\title{
Incidence of SARS-CoV-2 infection among asymptomatic frontline health workers in Los Angeles County, California
}

1. Megan Halbrook, MPH, Department of Epidemiology, Jonathan and Karin Fielding School of Public Health, University of California, Los Angeles, USA

2. Adva Gadoth, MPH, PhD, Department of Epidemiology, Jonathan and Karin Fielding School of Public Health, University of California, Los Angeles, USA

3. Rachel Martin-Blais, MD, Department of Pediatrics, David Geffen School of Medicine at University of California, Los Angeles, Los Angeles, CA, USA

4. Ashley Grey, MD, Division of Pediatric Hematology/Oncology, David Geffen School of Medicine at University of California, Los Angeles, Los Angeles, CA, USA

5. Deisy Contreras, PhD, David Geffen School of Medicine at University of California, Los Angeles, Los Angeles, CA, USA

6. Saman Kashani, MD, Los Angeles County Fire Department, Los Angeles CA, USA

7. Clayton Kazan, Los Angeles County Fire Department, Los Angeles CA, USA

8. Brian Kane, Los Angeles County Fire Department, Los Angeles CA, USA

9. Nicole H. Tobin, MD, Department of Pediatrics, David Geffen School of Medicine at University of California, Los Angeles, Los Angeles, CA, USA

10. Jennifer A. Fulcher, MD, PhD, Division of Infectious Diseases, Department of Medicine, David Geffen School of Medicine at University of California, Los Angeles, Los Angeles, CA, USA

11. Sarah L. Brooker, PhD, Department of Pediatrics, David Geffen School of Medicine at University of California, Los Angeles, Los Angeles, CA, USA

12. Scott G. Kitchen, PhD, Division of Hematology/Oncology, David Geffen School of Medicine at University of California, Los Angeles, Los Angeles, CA, USA

13. Emmanuelle Faure-Kumar, PhD, Department of Medicine, Division of Digestives Diseases, University of California, Los Angeles, Los Angeles, CA, USA

14. Otto O. Yang, MD, Division of Infectious Diseases, Department of Medicine, David Geffen School of Medicine at University of California, Los Angeles, Los Angeles, CA, USA

15. Kathie G. Ferbas, PhD, David Geffen School of Medicine at University of California, Los Angeles, Los Angeles, CA, USA

16. Grace M. Aldrovandi, MD, David Geffen School of Medicine at University of California, Los Angeles, Los Angeles, CA, USA

17. Anne W. Rimoin, MPH, PhD, Department of Epidemiology, Jonathan and Karin Fielding School of Public Health, University of California, Los Angeles, USA

Authors 1, 2, 3, 4 contributed equally to this manuscript.

Corresponding Author:

Dr. Anne Rimoin

UCLA School of Public Health

650 Charles E. Young Drive South

CHS 41-275, Box 177220

Los Angeles, CA 90095

arimoin@ucla.edu

(310) 825-2096
Alternate Corresponding Author:

Megan Halbrook

UCLA School of Public Health

650 Charles E. Young Drive South

CHS 41-275, Box 177220

Los Angeles, CA 90095

meganhalbrook@ucla.edu 
medRxiv preprint doi: https://doi.org/10.1101/2020.11.18.20234211; this version posted November 21, 2020. The copyright holder for this preprint (which was not certified by peer review) is the author/funder, who has granted medRxiv a license to display the preprint in perpetuity. It is made available under a CC-BY-NC-ND 4.0 International license.

\begin{abstract}
Beginning April 8, 2020, we enrolled 1787 frontline heath workers who were asymptomatic for COVID19 into a longitudinal surveillance study. During that time 4 healthcare workers and 6 first responders tested positive for SARS-CoV-2 by RT-PCR. Additionally, 43 healthcare workers and 55 first responders had detectable IgG antibodies to SARS-CoV-2.
\end{abstract}

Key words: COVID, coronavirus, healthcare workers, surveillance, first responders 
medRxiv preprint doi: https://doi.org/10.1101/2020.11.18.20234211; this version posted November $21,2020$. The copyright holder for this preprint (which was not certified by peer review) is the author/funder, who has granted medRxiv a license to display the preprint in perpetuity.

It is made available under a CC-BY-NC-ND 4.0 International license .

\section{Introduction}

Our understanding of the epidemiology and pathogenesis of severe acute respiratory syndrome coronavirus 2 (SARS-CoV-2) infection remains incomplete. Frontline health workers are at heightened risk for exposure to and transmission of SARS-CoV-2 due to their close physical contact with persons requiring medical attention and interventions and the close work and rest spaces. They also represent an ideal population for the study of asymptomatic and minimally symptomatic spread of COVID-19, with vested interests in frequent screening $[1,2]$. With this in mind, we enrolled a cohort of asymptomatic persons employed by the University of California, Los Angeles (UCLA) Health system and the Los Angeles County Fire Department (LACoFD) into a longitudinal research study designed to assess SARS-CoV-2 attack rates, exposure risks, and correlates of immunity during the course of the COVID-19 pandemic in Los Angeles County.

\section{Methods}

UCLA Health employs over 38,000 individuals across four hospitals and over 180 primary care practices in Los Angeles County. LACoFD is responsible for the emergency response of 4 million residents across Los Angeles County, and staffs 175 fire stations and all public lifeguard towers with approximately 4000 frontline personnel. Beginning on April 8, 2020 and May 19, 2020, respectively, health system workers (HSW) employed by UCLA Health-including those with and without direct patient care responsibilities - and LACoFD first responders (FR) from eight battalions - including firefighters, paramedics, lifeguards, and dispatchers-were invited to enroll in this study. Eligible participants were over 18 years of age and free of new symptoms associated with COVID-19 in the 2 days prior to enrollment. 
medRxiv preprint doi: https://doi.org/10.1101/2020.11.18.20234211; this version posted November $21,2020$. The copyright holder for this preprint (which was not certified by peer review) is the author/funder, who has granted medRxiv a license to display the preprint in perpetuity.

It is made available under a CC-BY-NC-ND 4.0 International license .

Participants were asked to provide monthly blood samples and up to biweekly self-collected midturbinate nasal swabs at their workplace; participants also responded to online questionnaires following sample collection to assess demographics and potential exposures to SARS-CoV-2. Nasal swabs were tested for the presence of SARS-CoV-2 using the FDA EUA approved Abbott Molecular dual target realtime multiplex PCR assay for the detection of SARS-CoV-2 RNA. Blood samples were analyzed by enzyme-linked immunosorbent assay (ELISA) to detect anti-SARS-CoV-2 spike receptor-binding domain $\operatorname{lgG}$, as previously described [3, 4].

Tabular counts, attack rates and associations between seroprevalence and demographic factors and occupational exposures were calculated using SAS statistical software version 9.4 (Cary, NC). While some participants may have received additional outside testing prior to enrollment or in between study visits, test results shown here reflect only SARS-CoV-2 PCR and serology performed as a part of study activities.

This study was approved by the UCLA institutional review board on March 25, 2020. New enrollments and follow-up visits are ongoing; results reported here reflect data gathered through August 31, 2020.

\section{Results}

From April through August, 2020, we enrolled 1108 HSW and 679 FR. Those aged 60 and older accounted for $4.9 \%$ of HSW and $2.2 \%$ of FR. Women accounted for almost two-thirds of enrolled HSW (64\%), but only a small minority of study FR (6.0\%). A majority (add \% that include at least 1 exposure) of frontline workers in both groups reported conducting procedures with potential for exposure to COVID19 patients, clinical samples, or work spaces (Table 1). 
medRxiv preprint doi: https://doi.org/10.1101/2020.11.18.20234211; this version posted November $21,2020$. The copyright holder for this preprint (which was not certified by peer review) is the author/funder, who has granted medRxiv a license to display the preprint in perpetuity.

It is made available under a CC-BY-NC-ND 4.0 International license .

During these initial months of observation, 4 (0.4\%) HSW and $6(0.9 \%)$ FR tested positive for SARS-CoV-2 by RT-PCR, with 22 (2\%) HSW and 12 (1.8\%) FR returning indeterminate PCR results. Thus, a five-month attack rate of $0.37-2.4 \%$ among HSW, and a four-month attack rate of $0.91-2.72 \%$ was determined for FR. Attack rates between these two groups were not significantly different from one another.

Forty-three HSW (3.9\%) had or developed detectable IgG antibodies to SARS-CoV-2 during the study period; among FR, 55 (8.1\%) had detectable IgG. Among those with indeterminate PCR tests, 19 (86\%) HCW and $8(66 \%)$ first responders did not have or had not yet developed detectable antibodies. Thirtyeight (3.4\%) HSW and 49 (7.2\%) FR had detectable SARS-CoV-2 antibodies without known history of infection during the initial study period (Table 1). Notably, among those who tested positive by PCR, two-thirds of first responders $(n=4)$ and half of HSW $(n=2)$ displayed active infection in late June.

Across both cohorts, rates of seroreactivity did not differ by demographic characteristics, job role, or performed medical procedures. Among the FR, sharing your living space with six or more people was associated with detection of SARS-CoV-2 antibodies ( $p=0.024)$. The odds of seroreactivity among those living with six or more persons was 7 times greater compared to those living alone (95\% $\mathrm{Cl}: 1.36-36.10$ ). This relationship was not observed across other household sizes (2-5 persons), nor among the HSW.

\section{Discussion}

These preliminary baseline data represent the first descriptions of an ongoing longitudinal study of frontline workers in Los Angeles county. As a whole, rates of active infection in this population were lower than in the general population as reported by the LA County Department of Public Health (LACDPH) during the same period [5]. However, a late June peak in active infections among our cohort does appear to mirror the larger LA community, which saw its positive test rate spike in mid-July. 
medRxiv preprint doi: https://doi.org/10.1101/2020.11.18.20234211; this version posted November $21,2020$. The copyright holder for this preprint (which was not certified by peer review) is the author/funder, who has granted medRxiv a license to display the preprint in perpetuity.

It is made available under a CC-BY-NC-ND 4.0 International license .

The low overall incidence observed could be indicative of proper and widespread use of personal protective equipment in these high-risk occupational settings, as universal masking protocols were in place in both work settings. Healthy worker bias is likely also an important explanatory factor in our recruitment of asymptomatic and mostly younger adults (below age 60), and in our finding of low infection prevalence among a population at the front lines of SARS-CoV-2 exposure.

Our results are contextualized by SARS-CoV-2 infection and exposure rates demonstrated in other studies of frontline health workers. In a convenience sample from 13 academic medical centers across the United States (including UCLA Health), only $6 \%$ of healthcare workers caring for COVID-19 patients displayed antibody evidence of SARS-CoV-2 infection [6]. Other analogous US health worker cohorts found rates of PCR positivity between $3.6-6.5 \%$ and antibody prevalence of $7.6 \%[7,8]$. The lower prevalence of serologic markers for SARS-CoV-2 infection observed in our study makes sense given our inclusion of workers across a spectrum of direct, indirect, and no occupational exposure to COVID-19 patients.

An investigation of SARS-CoV-2 infections by the LACDPH found that, from February-May, 2020, 10\% of incident cases reported across the county occurred among healthcare workers [9]. Thus, despite low rates of incident infection observed among HSW and FR, frontline health workers make up an important proportion of new cases identified across the county. Notably, LACDPH investigated positive-testing healthcare workers across 27 distinct settings and identified correctional facilities, schools, and longterm care facilities as outbreak hotspots [9]. In contrast, this study enrolled workers from hospital, outpatient, and first response settings, which may help account for the lower prevalence of positive PCR tests and antibody markers observed. While some high-risk vocations weren't targeted by this study, 
medRxiv preprint doi: https://doi.org/10.1101/2020.11.18.20234211; this version posted November 21, 2020. The copyright holder for this preprint (which was not certified by peer review) is the author/funder, who has granted medRxiv a license to display the preprint in perpetuity. It is made available under a CC-BY-NC-ND 4.0 International license .

$11 \%$ of HSW reported secondary healthcare jobs in these settings: fifteen participants held positions at long-term care facilities and two reported additional roles at colleges.

While this study was open to all LACoFD and UCLA Health employees, work schedules and study logistics may have created barriers to participation. Rolling enrollment from April 8 to August 31, 2020 may also have introduced some measure of temporal confounding into our analysis, given the variable testing infrastructure, governmental policies, and communal incidence of SARS-CoV-2 infection in LA County over this timeframe. Thus, further analysis at the conclusion of study activities should include an enrollment date-adjusted examination of biological markers of infection. 
medRxiv preprint doi: https://doi.org/10.1101/2020.11.18.20234211; this version posted November 21, 2020. The copyright holder for this preprint (which was not certified by peer review) is the author/funder, who has granted medRxiv a license to display the preprint in perpetuity. It is made available under a CC-BY-NC-ND 4.0 International license .

\section{Acknowledgements}

The authors would like to acknowledge the contributions of Patrick Arena, Angie Barrall, Cindy Beard,

Sylvia Tangney, Michael Mengual, Marjorie Weiman, Gabby Merlo, Sergio Duron, Faith Landsman, Sarah

Zabih, Ana Zamora, Monica Saavedra, Hwee Ng, Lorena Porras-Javier, and La Quinta N. Montgomery.

\section{Footnote}

This work was supported by AIDS Healthcare Foundation, The Shurl and Kay Curci Foundation, Elizabeth

R. Koch Foundation, The Horn Foundation, and Steven \& Alexandra Cohen Foundation.

The authors have no conflicts of interest to declare.

Corresponding Author:

Dr. Anne Rimoin

UCLA School of Public Health

650 Charles E. Young Drive South

CHS 41-275, Box 177220

Los Angeles, CA 90095

arimoin@ucla.edu

(310) 825-2096 
medRxiv preprint doi: https://doi.org/10.1101/2020.11.18.20234211; this version posted November 21, 2020. The copyright holder for this preprint (which was not certified by peer review) is the author/funder, who has granted medRxiv a license to display the preprint in perpetuity.

It is made available under a CC-BY-NC-ND 4.0 International license .

\section{References}

1. CDC. Cluster of severe acute respiratory syndrome cases among protected health-care workers-Toronto, Canada, April 2003. MMWR Morbidity and mortality weekly report 2003; 52:433-6.

2. Ho AS, Sung JJY, Chan-Yeung M. An outbreak of severe acute respiratory syndrome among hospital workers in a community hospital in Hong Kong. Annals of internal medicine 2003; 139:564-7.

3. Ibarrondo FJ, Fulcher JA, Goodman-Meza D, et al. Rapid Decay of Anti-SARS-CoV-2 Antibodies in Persons with Mild Covid-19. The New England journal of medicine 2020; 383:1085-7.

4. Stadlbauer D, Amanat F, Chromikova V, et al. SARS-CoV-2 Seroconversion in Humans: A Detailed Protocol for a Serological Assay, Antigen Production, and Test Setup. Current protocols in microbiology 2020; 57:e100.

5. Los Angeles County Department of Public Health. LA County COVID-19 Surveillance Dashboard. Available at: http://dashboard.publichealth.lacounty.gov/covid19 surveillance dashboard/.

6. Self WH, Tenforde MW, Stubblefield WB, et al. Seroprevalence of SARS-CoV-2 Among Frontline Health Care Personnel in a Multistate Hospital Network - 13 Academic Medical Centers, April-June 2020. MMWR Morbidity and mortality weekly report 2020; 69:1221-6.

7. Vahidy FS, Bernard DW, Boom ML, et al. Prevalence of SARS-CoV-2 Infection Among Asymptomatic Health Care Workers in the Greater Houston, Texas, Area. JAMA Network Open 2020; 3:e2016451-e.

8. Stubblefield WB, Talbot HK, Feldstein LR, et al. Seroprevalence of SARS-CoV-2 Among Frontline Healthcare Personnel During the First Month of Caring for Patients With COVID-19-Nashville, Tennessee. Clinical Infectious Diseases 2020. 
medRxiv preprint doi: https://doi.org/10.1101/2020.11.18.20234211; this version posted November 21, 2020. The copyright holder for this preprint (which was not certified by peer review) is the author/funder, who has granted medRxiv a license to display the preprint in perpetuity.

It is made available under a CC-BY-NC-ND 4.0 International license .

9. Hartmann S, Rubin Z, Sato H, O Yong K, Terashita D, Balter S. Coronavirus Disease 2019 (COVID-19)

Infections Among Healthcare Workers, Los Angeles County, February-May 2020. Clinical Infectious

Diseases 2020. 
Table 1. Test Results \& Participant Demographics

\begin{tabular}{|c|c|c|c|c|c|c|}
\hline & \multicolumn{3}{|c|}{ HSW $(n=1108)$} & \multicolumn{3}{|c|}{ FR $(n=679)$} \\
\hline & $\begin{array}{c}\text { All } \\
n=1108\end{array}$ & $\begin{array}{c}\text { Antibodies } \\
\text { Detected } \\
n=43\end{array}$ & $\begin{array}{c}\text { Antibodies } \\
\text { not Detected } \\
\text { n=1065 }\end{array}$ & All & $\begin{array}{c}\text { Antibodies } \\
\text { Detected } \\
\text { n=55 }\end{array}$ & $\begin{array}{c}\text { Antibodies } \\
\text { not Detected } \\
\text { n=624 }\end{array}$ \\
\hline & n $(\operatorname{col} \%)$ & n $(\operatorname{col} \%)$ & n $(\operatorname{col} \%)$ & n $(\operatorname{col} \%)$ & n $(\operatorname{col} \%)$ & n $(\operatorname{col} \%)$ \\
\hline \multicolumn{7}{|l|}{ PCR Result } \\
\hline Positive & $4(0.36)$ & $2(4.65)$ & $2(0.19)$ & $6(0.88)$ & $2(3.64)$ & $4(0.64)$ \\
\hline Indeterminant & $22(1.99)$ & $3(6.98)$ & $19(1.78)$ & $12(1.77)$ & $4(7.27)$ & $8(1.28)$ \\
\hline Negative & $1082(97.65)$ & $38(88.37)$ & $1044(98.03)$ & $661(97.35)$ & $49(89.09)$ & $612(98.08)$ \\
\hline \multicolumn{7}{|l|}{ Age } \\
\hline $20-29$ & $172(15.52)$ & $10(23.81)$ & $162(16.43)$ & $53(7.81)$ & $5(10.2)$ & $48(7.74)$ \\
\hline $30-39$ & 418 (37.73) & $15(35.71)$ & $403(40.87)$ & $237(34.90)$ & $23(46.94)$ & $214(34.52)$ \\
\hline $40-49$ & $235(21.21)$ & $5(11.9)$ & $230(23.33)$ & $182(26.80)$ & $12(24.49)$ & $170(27.42)$ \\
\hline
\end{tabular}




\begin{tabular}{|c|c|c|c|c|c|c|}
\hline $50-59$ & $148(13.36)$ & $8(19.05)$ & $140(14.2)$ & $182(26.80)$ & $8(16.33)$ & $174(28.06)$ \\
\hline $60+$ & $55(4.96)$ & $4(9.52)$ & $51(5.17)$ & $15(2.21)$ & $1(2.04)$ & $14(2.26)$ \\
\hline \multicolumn{7}{|l|}{ Sex } \\
\hline Male & $312(28.16)$ & $15(35.71)$ & $297(30.24)$ & $629(92.64)$ & $46(93.88)$ & $583(93.88)$ \\
\hline Female & $710(64.08)$ & $27(64.29)$ & $683(69.55)$ & $41(6.04)$ & $3(6.12)$ & $38(6.12)$ \\
\hline \multicolumn{7}{|l|}{ Race } \\
\hline Asian & $300(27.08)$ & $13(30.23)$ & $287(26.95)$ & $36(5.30)$ & $1(2.04)$ & $35(5.61)$ \\
\hline American Indian/ Alaskan Native & $9(0.81)$ & $0(0)$ & $9(0.85)$ & $11(1.62)$ & $0(0)$ & $11(1.76)$ \\
\hline Black/ African American & $47(4.24)$ & $3(6.98)$ & $44(4.13)$ & $41(6.04)$ & $4(8.16)$ & $37(5.93)$ \\
\hline Native Hawaiian/ Pacific Islander & $34(3.07)$ & $2(4.65)$ & $32(3)$ & $18(2.65)$ & $0(0)$ & $18(2.88)$ \\
\hline White & $566(51.08)$ & $21(48.84)$ & $545(51.17)$ & $433(63.77)$ & $13(26.53)$ & $227(36.38)$ \\
\hline Other & $94(8.48)$ & $1(2.33)$ & $93(8.73)$ & $98(14.43)$ & $8(16.33)$ & $90(14.42)$ \\
\hline \multicolumn{7}{|l|}{ Ethnicity } \\
\hline Hispanic/Latino & $139(12.55)$ & $6(15.38)$ & $133(14.18)$ & $212(31.22)$ & $21(46.67)$ & $191(33.63)$ \\
\hline Non-Hispanic/ Latino & $788(71.12)$ & $33(84.62)$ & 755 (80.49) & $322(47.42)$ & $19(42.22)$ & $303(53.35)$ \\
\hline
\end{tabular}




\begin{tabular}{|c|c|c|c|c|c|c|}
\hline Prefer not to say & $50(4.51)$ & $0(0)$ & $50(5.33)$ & $79(11.63)$ & $5(11.11)$ & $74(13.03)$ \\
\hline \multicolumn{7}{|c|}{ Number of persons sharing living } \\
\hline I live by myself & $187(16.88)$ & $10(23.81)$ & $177(18.01)$ & $54(7.95)$ & $2(4.08)$ & $52(8.51)$ \\
\hline 2 people & 407 (36.37) & $14(33.33)$ & $393(39.98)$ & $177(26.07)$ & $16(32.65)$ & $161(26.35)$ \\
\hline 3 people & $163(14.71)$ & $11(26.19)$ & $152(15.46)$ & $137(20.18)$ & $6(12.24)$ & $131(21.44)$ \\
\hline 4 people & $169(15.25)$ & $4(9.52)$ & $165(16.79)$ & $180(26.51)$ & $12(24.49)$ & $168(27.5)$ \\
\hline 5 people & $65(5.87)$ & $1(2.38)$ & $64(6.51)$ & $79(11.63)$ & $6(12.24)$ & $73(11.95)$ \\
\hline 6 or more people & $34(3.07)$ & $2(4.76)$ & $32(3.26)$ & $33(4.86)$ & $7(14.29)$ & $26(4.26)$ \\
\hline \multicolumn{7}{|c|}{ Community contact with symptomapic person } \\
\hline Yes & $28(2.53)$ & $2(4.76)$ & $26(97.36)$ & $31(4.57)$ & $4(8.33)$ & $27(4.38)$ \\
\hline No & $998(90.07)$ & $40(95.24)$ & $958(97.36)$ & $634(93.37)$ & $44(91.67)$ & $590(95.62)$ \\
\hline \multicolumn{7}{|c|}{ Workplace Department (HSW only) } \\
\hline Emergency Department & $73(6.59)$ & $3(7.32)$ & $70(7.58)$ & & & \\
\hline Intensive care unit & $244(22.02)$ & $15(36.59)$ & $229(24.78)$ & & & \\
\hline
\end{tabular}




\begin{tabular}{|c|c|c|c|c|c|c|}
\hline Hospital ward & $167(15.07)$ & $4(9.76)$ & $163(17.64)$ & & & \\
\hline Pulmonology serivce & $20(1.81)$ & $1(2.44)$ & $19(2.06)$ & & & \\
\hline Anesthesiology service & $47(4.24)$ & $1(2.44)$ & $46(4.98)$ & & & \\
\hline ENT/Otolaryngology serivce & $4(0.36)$ & $0(0)$ & $4(0.43)$ & & & \\
\hline Infectious disease service & $22(1.99)$ & $0(0)$ & $22(2.3)$ & & & \\
\hline Surgical unit & $77(6.95)$ & $2(4.88)$ & $75(8.12)$ & & & \\
\hline Other Hospital position & $296(26.71)$ & $13(31.71)$ & $283(30.63)$ & & & \\
\hline I work remotely & $15(1.35)$ & $2(4.88)$ & $13(1.41)$ & & & \\
\hline \multicolumn{7}{|l|}{ edures Conducted } \\
\hline Nasopharyngeal (NP) swabs & $156(14.08)$ & $3(6.98)$ & $153(14.37)$ & & & \\
\hline Broncholaveolar lavage (BAL) & $69(6.23)$ & $4(9.3)$ & $65(6.1)$ & & & \\
\hline Collecting Sputum & $91(8.21)$ & $3(6.98)$ & $88(8.26)$ & & & \\
\hline Intubation/airway procedures & $191(17.24)$ & $7(16.28)$ & $184(17.28)$ & $91(13.40)$ & $6(12.24)$ & $85(13.62)$ \\
\hline CPR & $41(3.70)$ & $1(2.33)$ & $40(3.76)$ & $227(33.43)$ & $21(42.86)$ & $206(33.01)$ \\
\hline COVID+ patient care & $306(27.62)$ & $16(37.21)$ & $290(27.23)$ & & & \\
\hline Respiratory therapy & $88(7.94)$ & $6(13.95)$ & $82(7.7)$ & & & \\
\hline Drawing blood from COVID+ & $124(11.19)$ & 8 (18.6) & $116(10.86)$ & & & \\
\hline
\end{tabular}


patients

Cleaning hospital rooms or care

spaces

Cleaning high touch surfaces

Cleaning non-patient spaces

Collecting fecal/rectal samples

Clinical laboratory work

SARS CoV-2-research-lab

work/processing

Trauma medicine

Arrests

Servicing homeless encampments

Routine traffic stops

Minor house calls

Telephone-based emergency

dispatch

None

\begin{tabular}{|c|c|c|c|c|c|}
\hline 85 (7.67) & $3(6.98)$ & $82(7.7)$ & $225(33.14)$ & $18(36.73)$ & 207 (33.17) \\
\hline $245(22.11)$ & $10(23.26)$ & $235(22.07)$ & $472(69.51)$ & $31(63.27)$ & $441(70.67)$ \\
\hline $160(14.44)$ & $5(11.63)$ & $155(14.55)$ & & & \\
\hline $59(5.32)$ & $2(4.65)$ & $57(5.35)$ & & & \\
\hline $45(4.06)$ & $1(2.33)$ & $44(4.13)$ & & & \\
\hline \multirow[t]{7}{*}{$22(1.99)$} & $1(2.33)$ & $21(1.97)$ & & & \\
\hline & & & $361(53.17)$ & $24(48.98)$ & $337(54.01)$ \\
\hline & & & $98(14.43)$ & $10(20.41)$ & $88(14.1)$ \\
\hline & & & $164(24.15)$ & $11(22.45)$ & $153(24.52)$ \\
\hline & & & $37(5.45)$ & $3(6.12)$ & $34(5.45)$ \\
\hline & & & $86(12.67)$ & $5(10.2)$ & $81(12.98)$ \\
\hline & & & $99(14.58)$ & $5(10.2)$ & $94(15.06)$ \\
\hline 440 (39.71) & $19(44.19)$ & $421(39.53)$ & $111(16.35)$ & 9 (18.37) & $102(16.35)$ \\
\hline
\end{tabular}


$*$ chi-sq p-value for FR cohort $=0.0244$ 